\title{
PERAN VISUAL EVOKED POTENTIAL PADA PASIEN DIABETES MELITUS TIPE-2 DENGAN DAN TANPA RETINOPATI DIABETIK
}

\author{
ROLE OF VISUAL EVOKED POTENTIAL IN TYPE-2 DIABETES MELLITUS WITH AND \\ WITHOUT DIABETIC RETINOPATHY
}

Bill Jones Tanawal, * Melke Joanne Tumboimbela, ${ }^{* *}$ Corry Novita Mahama**

\section{ABSTRACT}

Introduction: Diabetic retinopathy (DR) is a common complication of type-2 diabetes mellitus (T2DM). Minimal functional change of neural layers of the retina occurs before structural changes, thus undetected by funduscopy. This damage could be identified earlier by P100 latency changes in visual evoked potential (VEP).

Aims: To find the characteristic of P100 in T2DM with and without DR, its correlation with the duration of the disease and the level of fasting blood glucose (FBG).

Methods: A cross sectional analysis study was conducted in Prof. dr. R.D. Kandou Hospital, Manado, from November 2017-January 2018. T2DM patients aged 18-60 with visual acuity $\geq 6 / 60$, without neuro-ophtalmological disorders and other metabolic diseases. P100 latency was measured using VEP with reversed checkerboard stimulation.

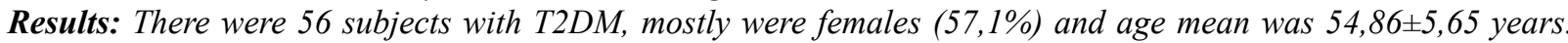
Delayed P100 latency occurred in 85,7\% subjects. Diabetic retinopathy subjects showed delayed P100 latency on right (92,31\%) and left (88\%) eyes while T2DM subjects without retinopathy showed delayed P100 latency on both eyes $70 \%$. There were strong and significant positive correlation between the duration of T2DM and P100 latency on the right and left eyes. There was no significant correlation between fasting blood glucose (FBG) level and P100 latency.

Discussions: Delayed P100 latency occurs in T2DM patients with and without retinopathy. The duration of T2DM correlates with the delay of P100 latency but not with the level of FBG.

Keywords: Diabetic retinopathy, P100, type-2 diabetes mellitus, visual evoked potential

\section{ABSTRAK}

Pendahuluan: Retinopati diabetik adalah suatu komplikasi yang umum terjadi pada diabetes melitus tipe-2 (DMT2). Sebelum terjadinya perubahan struktural, lapisan neuron retina pasien DMT2 sudah mengalami perubahan fungsional minimal yang tidak terdeteksi dengan funduskopi. Hal ini dapat diidentifikasi lebih dini berdasarkan gambaran latensi gelombang P100 pada pemeriksaan visual evoked potential (VEP).

Tujuan: Untuk mengetahui karakteristik nilai gelombang P100 pada pasien DMT2 dengan dan tanpa retinopati diabetik, serta hubungannya dengan lama penyakit dan kadar glukosa darah puasa (GDP).

Metode: Penelitian analitik dengan desain potong lintang terhadap pasien DMT2 yang dirawat di RSUP Prof. dr. R.D. Kandou, Manado periode November 2017-Januari 2018. Subjek berusia 18-60 tahun dengan visus $\geq 6 / 60$ tanpa adanya kelainan neuro-oftamologi dan penyakit metabolik lain. Dilakukan perekaman VEP menggunakan stimulasi reversed checkerboard dilanjutkan pengukuran latensi gelombang P100.

Hasil: Didapatkan 56 subjek, paling banyak perempuan (57,1\%) dan rerata usia 54,86 $\pm 5,65$ tahun. Latensi P100 memanjang pada $85,7 \%$ subjek. Pada subjek dengan retinopati ditemukan mayoritas mengalami pemanjangan latensi pada mata kanan $(92,31 \%)$ dan mata kiri $(88 \%)$, sedangkan pada subjek tanpa retinopati ditemukan pemanjangan latensi kedua mata adalah 70\%. Terdapat hubungan bermakna dengan korelasi positif kuat antara lamanya DMT2 dan latensi P100 kanan dan kiri. Tidak terdapat hubungan yang bermakna antara kadar GDP dan latensi P100.

Diskusi: Pemanjangan latensi P100 terjadi pada subjek DMT2 dengan dan tanpa retinopati. Lamanya DMT2 berhubungan dengan pemanjangan latensi P100, tetapi kadar GDP tidak berhubungan dengan pemanjangan latensi P100.

Kata kunci: Diabetes melitus tipe-2, P100, retinopati diabetik, visual evoked potential

*Departemen Neurologi FK Universitas Sam Ratulangi/RSUP Prof. dr. R.D. Kandou, Manado. Korespondensi: billjones140@gmail.com.

\section{PENDAHULUAN}

Saat ini terdapat kecenderungan peningkatan angka insiden dan prevalensi DMT2 di dunia, termasuk Indonesia. WHO memprediksi kenaikan jumlah penyandang DMT2 di Indonesia dari 8,4 juta pada tahun 2000 menjadi 21,3 juta pada tahun 2030 .
Adapun International Diabetes Federation (IDF) memprediksi kenaikan dari 9,1 juta pada tahun 2014 menjadi 14,1 juta pada tahun $2035 .^{1-2}$

Retinopati diabetik (RD) adalah suatu komplikasi serius akibat DMT2 yang terjadi karena kerusakan mikrovaskular retina. Sasongko dkk pada 
tahun 2017 mendapatkan prevalensi RD di Indonesia sebesar 43,1\%. Pasien DMT2 memiliki risiko 25 kali lebih besar untuk mengalami kebutaan dibanding non-DMT2. Sebanyak 21\% pasien dengan DMT2 memiliki RD pada saat pertama kali terdiagnosis DMT2. Pada sebagian besar kasus biasanya asimptomatik sehingga menyebabkan keterlambatan penanganan yang efektif. Kontrol glikemik yang baik secara signfikan akan menurunkan risiko komplikasi visual pada DMT2. ${ }^{3-6}$

Penelitian menunjukkan adanya neurodegenerasi pada lapisan retina pasien DMT2, yaitu adanya defek minimal pada lapisan neurosensorik retina sebelum terjadinya perubahan struktural akibat lesi mikrovaskular. Sel-sel ganglion retina adalah sel yang pertama kali terlibat dan memiliki derajat apoptosis tertinggi pada tahap neurodegenerasi tersebut. Pada tahap ini masih belum terdapat keluhan gangguan visual atau gambaran retinopati melalui pemeriksaan funduskopi. ${ }^{7-10}$

Visual evoked potential (VEP) merupakan suatu pemeriksaan elektrofisiologi untuk mengevaluasi jaras visual dari sel ganglion retina hingga korteks visual. Gelombang klasik VEP berbentuk gelombang "V', yang terdiri atas 3 komponen, yaitu gelombang awal berbentuk puncak negatif (N75), diikuti puncak positif yang besar (P100) dan puncak negatif yang lain (N145). Terdapat 3 macam pemeriksaan VEP yaitu patern-reversal VEP (PVEP), pattern onset/ offset VEP, dan flash VEP (FVEP). PVEP merupakan jenis pemeriksaan yang memiliki nilai akurasi yang baik dan sangat sensitif terhadap disfungsi sistem konduksi visual, yang dilakukan pada penelitian ini dan selanjutnya disebut sebagai VEP secara umum

Secara umum VEP efektif dalam mengidentifikasi kerusakan sel ganglion retina pada diabetes. Abnormalitas VEP pada DMT2 ditunjukkan dengan adanya pemajangan latensi P100. Deteksi dini RD dengan menggunakan VEP dapat membantu mencegah kehilangan fungsi penglihatan. ${ }^{8-13}$

Defisit neurologis pada DMT2 dapat melibatkan sistem visual pada tahap yang jauh lebih awal dan meningkat sesuai dengan peningkatan durasi penyakit. Pada hiperglikemia yang berkepanjangan, terdapat temuan patologis yang menujukkan adanya kerusakan struktural pada tingkat serabut saraf optikus yang bermielin. Terjadi penurunan aktivitas $\mathrm{Na}^{+} \mathrm{K}^{+}$ATP-ase pada daerah nodus dan paranodus serabut saraf bermielin. Hal ini menyebabkan peningkatan konsentrasi natrium aksonal, penurunan permeabilitas natrium membran nodus, dan blok konduksi selektif dengan adanya penurunan kecepatan konduksi. Iskemia, penurunan sintesis protein, deplesi myoinositol, peningkatan kadar sorbitol, dan akumulasi sitokin neuropoietik turut berkontribusi terhadap kehilangan serabut saraf optikus..$^{13-14}$

Gangguan sistem visual yang terjadi pada DMT2 dapat menurunkan kualitas hidup pasien. Kerusakan pada lapisan neurosensorik retina dan serabut saraf optikus dapat terjadi pada tahap yang lebih awal sebelum terjadinya perubahan struktural yang dapat terlihat pada funduskopi. Seiring dengan dengan peningkatan durasi penyakit dapat terjadi penurunan kecepatan konduksi yang menyebabkan pemanjangan latensi P100. Penting dan menarik untuk meneliti peran VEP dalam mendeteksi fungsi visual populasi DMT2, karena dapat membantu dalam peningkatan mutu diagnosis, tata laksana, pencegahan serta penentuan prognosis komplikasi visual pada pasien DMT2.

\section{TUJUAN}

Untuk mengetahui karakteristik nilai gelombang P100 pada pasien DMT2 dengan dan tanpa retinopati diabetik, serta hubungannya dengan lama penyakit dan kadar glukosa darah puasa (GDP).

\section{METODE}

Penelitian analitik dengan desain potong lintang terhadap pasien DMT2 yang rawat jalan poliklinik mata, saraf, dan penyakit dalam di RSUP Prof. dr. R.D. Kandou, Manado pada bulan November 2017-Januari 2018. Kriteria inkusi adalah pasien yang berusia 18-60 tahun, dalam keadaan sadar (Skala Koma Glasgow 15) dan kooperatif, serta bersedia diikutsertakan dalam penelitian. Kriteria eksklusi adalah aksis visus $<6 / 60$ (meter), pupil yang asimetris, gangguan pergerakan bola mata, retinopati diabetik proliferatif, serta riwayat penyakit makula, uveitis, trauma okular, operasi intraokular, katarak, glaukoma, kekeruhan vitreus, atau atrofi optik, hipertensi, penyakit serebrovaskular, gangguan lapang pandang, penggunaan obat levodopa, 
antiepilepsi, litium, dan anti tuberkulosis.

Subjek dilakukan anamnesis, pemeriksaan fisik, dan neurologi umum. Kadar GDP diukur dengan menggunakan alat pengukur glukosa darah. Pemeriksaan visus, ukuran pupil, lapang pandang, kisi-kisi Amsler (untuk memeriksa lapang pandang sentral), dan pemeriksaan okulomotor dilakukan di Poliklinik Neurooftalmologi-Neurootologi untuk menyingkirkan kriteria eksklusi. Selanjutnya dilakukan pemeriksaan oftamoskopi direk dengan dilatasi pupil.

Penilaian RD dilakukan berdasarkan kriteria International Clinical Disease Severity Scale (ICDSS) dan dibagi atas tidak tampak retinopati, $\mathrm{RD}$ nonproliferatif ( $\mathrm{RDN}$ ) ringan, $\mathrm{RDN}$ sedang, dan RDN berat. Pemeriksaan PVEP menggunakan mesin Dantec ${ }^{\circledR}$ dengan 2 channel amplifier, amplifikasi 20.000-1.000.000, low cut filter 1-3Hz, high cut filter $100-300 \mathrm{~Hz}, 200-300$ sweeps averaged untuk tiap perekaman, stimulus berupa reversed checkerboard berukuran $26 \mathrm{~mm}$ dengan kecepatan stimulus $2 \mathrm{~Hz}$, dan luminasi layar stimulus $60 \mathrm{~cd} / \mathrm{m}^{2}$ dengan kontras $80 \%$.

Pemasangan elektroda kepala berdasarkan sistem internasional 10-20 dengan menggunakan elektroda standar perekaman otak, dan impedans $<5 \mathrm{k} \Omega$. Secara berturut-turut elektroda aktif, referens, dan ground diletakkan di titik Oz, Fz, dan Cz. Standar perekaman menggunakan acuan International Society for Clinical Electrophysiology of Vision. Perekaman dilakukan di ruangan gelap dan tenang. Subjek duduk di depan layar monitor dengan jarak $100 \mathrm{~cm}$ dan diminta untuk memfiksasikan pandangan pada bagian tengah layar. Stimulasi monokular diberikan pada kedua mata secara bergantian. Parameter VEP yang digunakan adalah latensi P100. ${ }^{15}$

Untuk menentukan batas nilai normal latensi P100 yang sesuai parameter perekaman laboratorium neurofisiologi RSUP Prof. dr. R.D. Kandou, dilakukan pemeriksaan VEP pada 20 sampel $^{11}$ kelompok subjek normal, yaitu berusia 18-60 tahun, visus $>6 / 60 \mathrm{~m}$, bukan pasien DMT2 dan hipertensi, tidak memiliki kelainan di bidang neuro-oftalmologi dan retina, serta tidak terdapat riwayat penyakit kejadian serebrovaskular dan penggunaan obat levodopa, antiepilepsi, litium, atau antituberkulosis.

Pengolahan data menggunakan program SPSS versi 22. Penghitungan nilai rerata dan simpang baku dilakukan untuk data yang bersifat kuantitatif. Pengujian kemaknaan statistik dilakukan sesuai dengan karakteristik data penelitian. Batas kemaknaan statistik dipergunakan alfa 5\%. Selanjutnya dilakukan uji normalitas data menggunakan uji OneSample Kolmogorov-Smirnov dengan kesimpulan data terdistribusi normal. Data dianalisis dengan uji korelasi Pearson.

\section{HASIL}

Pada penelitian ini dilakukan penilaian latensi P100 pada 20 subjek normal dengan rentang usia 2230 tahun untuk dijadikan standar penentuan rentang nilai normal. Didapatkan hasil nilai normal latensi P100 pada laki-laki lebih panjang dibandingkan perempuan, baik pada mata kanan dan kiri. Nilai rerata latensi normal P100 pada laki-laki baik pada mata kanan dan kiri adalah 104,50 $\pm 1,080$, sedangkan perempuan yaitu $103,10 \pm 1,595$ dan $103,30 \pm 1,337$ (Tabel 1).

Tabel 1. Nilai Latensi P100 pada Populasi Normal $(n=20)$

\begin{tabular}{lcc}
\hline \multicolumn{1}{c}{ Parameter } & $\begin{array}{c}\text { Perempuan } \\
(\text { Rerata } \pm \text { SD) }\end{array}$ & $\begin{array}{c}\text { Laki-laki } \\
(\text { Rerata } \pm \text { SD) }\end{array}$ \\
\hline Latensi P100 mata kanan & $103,10 \pm 1,59$ & $104,50 \pm 1,08$ \\
Latensi P100 mata kiri & $103,30 \pm 1,33$ & $104,50 \pm 1,35$ \\
\hline
\end{tabular}

SD: standar deviasi.

Adapun subjek yang memenuhi kriteria penelitian ini sebanyak 56 subjek yang mayoritas perempuan $(57,1 \%)$ dan rerata usia $54,86 \pm 5,65$ tahun. Sebanyak $46,4 \%$ subjek memiliki lama penyakit DMT2 $<6$ tahun dan rerata lama DMT2

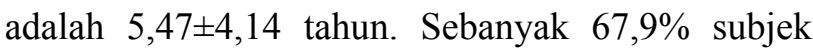
memiliki kadar GDP $>130 \mathrm{mg} / \mathrm{dl}$ dan rerata kadar GDP $170,23 \pm 52,56 \mathrm{mg} / \mathrm{dL}$ (Tabel 2). Pemeriksaan funduskopi didapatkan normal kedua mata pada kebanyakan subjek $(53,6 \%)$. Adapun pemeriksaan VEP diperoleh $85,7 \%$ subjek memiliki pemanjangan latensi P100 pada kedua mata. Pada subjek DMT2 dengan retinopati ditemukan pemanjangan latensi P100 mata kanan sebanyak $92,31 \%$ dan $88 \%$ mata kiri. Pada subjek DMT2 tanpa retinopati ditemukan pemanjangan latensi P100 mata kanan sebanyak 70\% dan $70,97 \%$ mata kiri. 
Tabel 2. Sebaran Karakteristik Subjek $(n=66)$

\begin{tabular}{|c|c|}
\hline Variabel & n $(\%)$ \\
\hline \multicolumn{2}{|l|}{ Jenis Kelamin } \\
\hline - Laki-laki & $24(42,9 \%)$ \\
\hline - Perempuan & $32(57,1 \%)$ \\
\hline \multicolumn{2}{|l|}{ Usia } \\
\hline - Minimal & 38 tahun \\
\hline - Maksimal & 60 tahun \\
\hline \multicolumn{2}{|l|}{ Lama DMT2 } \\
\hline - $<6$ tahun & $26(46,40)$ \\
\hline - 6-10 tahun & $23(41,10)$ \\
\hline - $>10$ tahun & $7(12,50)$ \\
\hline \multicolumn{2}{|l|}{ Kadar GDP } \\
\hline - $80-130 \mathrm{mg} / \mathrm{dl}$ & $18(32,10)$ \\
\hline - $\quad>130 \mathrm{mg} / \mathrm{dl}$ & $38(67,90)$ \\
\hline \multicolumn{2}{|l|}{ Funduskopi mata kanan } \\
\hline - Tidak tampak retinopati & $30(53,60)$ \\
\hline $\begin{array}{l}\text { - Retinopati diabetik non proliferatif } \\
\text { ringan }\end{array}$ & $12(21,40)$ \\
\hline $\begin{array}{l}\text { - Retinopati diabetik non proliferatif } \\
\text { sedang }\end{array}$ & $12(21,40)$ \\
\hline $\begin{array}{l}\text { - Retinopati diabetik non proliferatif } \\
\text { berat }\end{array}$ & $2(3,60)$ \\
\hline \multicolumn{2}{|l|}{ Funduskopi mata kiri } \\
\hline - Tidak tampak retinopati & $31(53,60)$ \\
\hline $\begin{array}{l}\text { - Retinopati diabetik non proliferatif } \\
\text { ringan }\end{array}$ & $14(21,40)$ \\
\hline $\begin{array}{l}\text { - Retinopati diabetik non proliferatif } \\
\text { sedang }\end{array}$ & $8(14,30)$ \\
\hline $\begin{array}{l}\text { - Retinopati diabetik non proliferatif } \\
\text { berat }\end{array}$ & $3(5,40)$ \\
\hline \multicolumn{2}{|l|}{ Latensi P100 mata kanan } \\
\hline - Normal & $8(14,30)$ \\
\hline - Memanjang & $48(85,70)$ \\
\hline \multicolumn{2}{|l|}{ Latensi P100 mata kiri } \\
\hline - Normal & $8(14,30)$ \\
\hline - Memanjang & $48(85,70)$ \\
\hline
\end{tabular}

DMT2: diabetes melitus tipe-2; GDP: glukosa darah puasa.

Pada analisis korelasi Pearson (Gambar 1 dan 2) didapatkan hubungan bermakna dengan korelasi positif kuat antara lamanya DMT2 dan latensi P100 mata kanan dan kiri $(\mathrm{p}<0,0001 ; \mathrm{r}=0,725$ dan $\mathrm{p}<0,0001 ; \mathrm{r}=0,757)$. Pada analisis hubungan antara kadar GDP dan latensi P100 mata kanan dan kiri tidak didapatkan adanya hubungan yang bermakna.
Tabel 3. Sebaran Karakteristik Subjek $(n=66)$

\begin{tabular}{lc}
\hline Variabel & Rerata \pm SD \\
\hline Lama DMT2 (tahun) & $5,47 \pm 4,14$ \\
Kadar GDP (mg/dl) & $170,23 \pm 52,56$ \\
Latensi P100 mata kanan (ms) & $111,63 \pm 7,13$ \\
Latensi P100 mata kiri (ms) & $111,93 \pm 7,66$ \\
\hline
\end{tabular}

DMT2: diabetes melitus tipe-2; GDP: glukosa darah puasa.

\section{PEMBAHASAN}

Interpretasi hasil VEP pada penelitian ini hanya dilakukan dengan identifikasi dan penilaian amplitudo dan latensi gelombang P100, karena merupakan parameter yang paling objektif. Adapun amplitudo memiliki nilai yang kurang reliabel akibat besarnya variabilitas. Walaupun sudah terdapat nilai normal yang dipublikasikan pada literatur, tetapi terdapat berbagai variasi antar laboratorium neurofisiologi terkait dengan nilai normal VEP. Oleh karena itu setiap laboratorium neurofisiologi sebaiknya memiliki data normatif dengan menggunakan stimulus dan parameter perekaman masing-masing. Apabila suatu laboratorium belum memiliki nilai rujukan normal, alternatif yang dapat digunakan adalah dengan melakukan pemeriksaan VEP pada minimal 20 sampel subjek normal untuk dilakukan penentuan nilai normal. ${ }^{10-12,16}$

Pada penelitian ini nilai yang didapatkan dari 20 subjek normal laki-laki dan perempuan berusia 22-30 tahun diperkirakan dapat mewakili populasi normal hingga kelompok umur 60 tahun. Faktor usia memang dapat memengaruhi latensi P100, tetapi pemanjangan latensi yang signifikan baru terjadi pada usia di atas 60 tahun, yaitu sekitar $3 \mathrm{~ms}$ per dekade. Pada masa remaja, latensi dapat sedikit menurun dan setelah itu hanya terjadi perubahan yang sangat minimal hingga usia 60 tahun. ${ }^{11-12}$

Pada penelitian ini didapatkan rerata latensi P100 pada laki-laki lebih panjang dibandingkan perempuan. Hasil ini sesuai dengan hasil penelitian Sharma $\mathrm{dkk}^{17}$ yang menyatakan bahwa nilai latensi P100 lebih panjang pada laki-laki dibandingkan perempuan. Jenis kelamin merupakan faktor fisiologis yang dapat memengaruhi latensi P100. Hal ini dihubungkan dengan perbedaan anatomis dan level hormonal (steroid). ${ }^{16-17}$

Pada penelitian ini didapatkan perempuan lebih banyak menderita DMT2 (57,10\%). Tingginya 


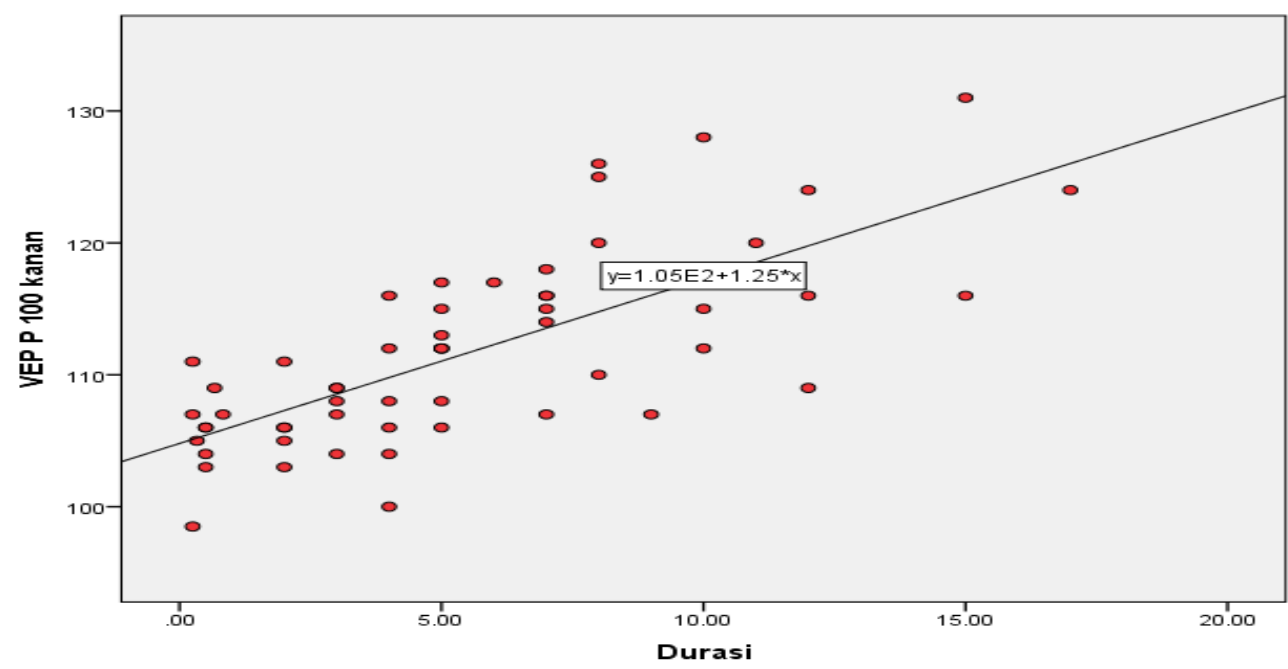

Gambar 1. Diagram Pencar Hubungan antara Durasi Diabetes Melitus Tipe-2 dan Latensi P100 Kanan

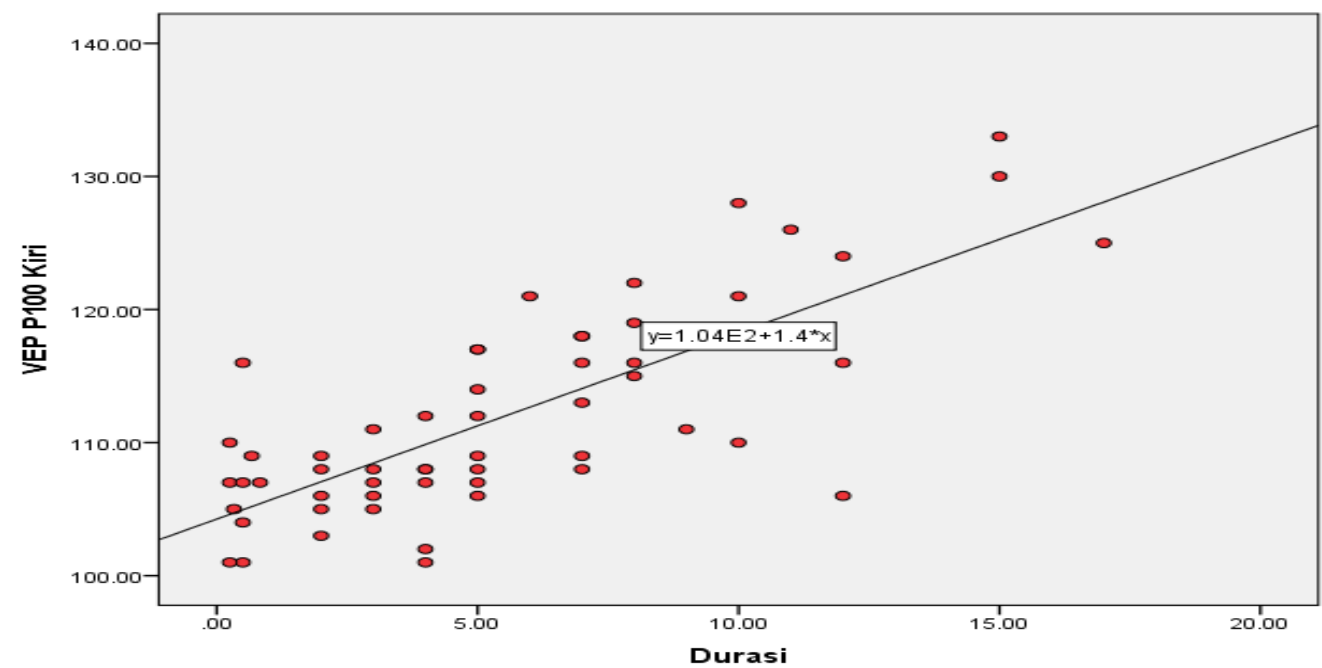

Gambar 2. Diagram Pencar Hubungan antara Durasi Diabetes Melitus Tipe-2 dan Latensi P100 Kiri

angka komplikasi DMT2 termasuk pada mata atau sistem visual dihubungkan dengan kontrol glikemik yang buruk. Salah satu parameter yang dipakai dalam sasaran pengendalian DMT2 adalah GDP $80-130 \mathrm{mg} /$ dl. ${ }^{1}$ Subjek pada penelitian ini memiliki status kontrol glikemik yang buruk dengan rerata GDP adalah $170,23 \mathrm{mg} / \mathrm{dl}$ dan sebanyak $67,9 \%$ pasien memiliki kadar GDP $>130 \mathrm{mg} / \mathrm{dl}$.

Pemeriksaan funduskopi merupakan metode untuk diagnosis klinis dengan melihat adanya lesi vaskular pada retina yang disebabkan oleh karena peningkatan permeabilitas vaskular, oklusi vaskular, dan iskemia retina. ${ }^{18}$ Pada pemeriksaan funduskopi direk sebanyak 53,6\% subjek tidak memiliki tanda- tanda retinopati pada kedua mata. Penelitian di Iran pada 40 pasien DMT2 didapatkan jumlah sampel tanpa retinopati yang lebih banyak, yaitu $65 \%$. Hal ini dapat disebabkan karena buruknya status kontrol glikemik pada subjek penelitian ini hingga menurunkan angka subjek DMT2 tanpa retinopati. ${ }^{6}$

Abnormalitas VEP pada DMT2 berupa pemanjangan latensi P100 telah dideskripsikan pada penelitian-penelitian sebelumnya, tetapi proporsi pasien DMT2 yang memiliki pemajangan latensi P100 masih cukup bervariasi. Hal ini dapat disebabkan oleh sejumlah faktor, seperti variabilitas kadar glukosa darah, ada tidaknya retinopati atau polineuropati, perbedaan stimulus dan parameter 
nilai normal VEP yang digunakan, serta perbedaan populasi dan metode penelitian. ${ }^{6}$ Pada penelitian ini, terdapat pemanjangan latensi $\mathrm{P} 100$ pada sebagian besar subjek (85,7\%). Hasil ini sesuai dengan penelitian sebelumnya yang menunjukkan adanya abnormalitas PVEP pada DMT2 melalui gambaran pemanjangan latensi P100. ${ }^{2,6,13}$

Abnormalitas respons VEP terjadi akibat kerusakan struktural di tingkat serabut saraf optikus yang bermielin atau sel ganglion retina sebelum perkembangan retinopati yang nyata. Hiperglikemia menyebabkan perpindahan glukosa ke dalam jalur poliol yang akan diubah menjadi sorbitol dan fruktosa. Zat-zat tersebut memiliki kecenderungan untuk menumpuk di dalam saraf dan akan meningkatkan kandungan cairan di dalam saraf. Hal ini menyebabkan penurunan kecepatan hantar saraf optikus yang terlihat melalui pemanjangan latensi P100. ${ }^{4,6,8}$

Pada penelitian ini terdapat pemanjangan latensi P100 pada mayoritas subjek yang memiliki retinopati pada mata kanan $(92,31 \%)$ dan mata kiri (88\%). Hasil yang sama didapatkan oleh Heravian dkk yang menunjukkan pemanjangan latensi P100 yang signifikan pada pasien DMT2 dengan dan tanpa retinopati diabetik dibandingkan dengan kontrol.6,19

Pada penelitian ini, subjek DMT2 tanpa retinopati juga memiliki pemanjangan latensi P100 mata kanan $(70 \%)$ dan mata kiri $(70,97 \%)$, sama dengan Gupta dkk yang mendapatkan abnormalitas VEP pada $80 \%$ pasien DMT2 tanpa retinopati. ${ }^{14-19}$ Pemanjangan latensi ini dapat merupakan tanda adanya proses neurodegenerasi atau kerusakan pada lapisan sel ganglion retina yang terjadi sebelum munculnya retinopati yang terdeteksi dengan funduskopi. ${ }^{20-21}$

Berdasarkan hasil analisis bivariat didapatkan hubungan bermakna dengan korelasi positif kuat antara lamanya DMT2 dan latensi P100. Hal ini sesuai dengan Chopra dkk pada 3 kelompok pasien DMT2 (30 pasien di tiap kelompok) dan 1 kelompok kontrol, didapatkan pemanjangan latensi P100 pada pasien DMT2 dan korelasi yang signifikan antara pemanjangan latensi P100 dan lamanya DMT2. ${ }^{13}$ Cheema dkk memperoleh hubungan signifikan antara lamanya DMT2 dan latensi P100 $(\mathrm{r}=0,63 ; \mathrm{p}=0,03) .{ }^{20}$
Sejumlah sitokin neuropoietik termasuk IL1, IL-6, leukaemia inhibitory factor (LIF), ciliary neurotrophic factor (CNTF), tumor necrosis factor (TNF)-alpha, dan tumor growth factor (TGF)-beta menunjukkan efek pleiotropik pada homeostasis sel glia dan neuron-neuron di sistem saraf pusat, perifer, dan otonom. Hal ini menyebabkan perlambatan konduksi jalur visual yang terlihat sebagai pemanjangan latensi P100. Seiring dengan meningkatnya durasi DMT2, terjadi peningkatan akumulasi mediator-mediator yang menyebabkan pemanjangan latensi yang lebih besar dibandingkan dengan pasien DMT2 dengan durasi penyakit yang lebih singkat. ${ }^{13}$

Pada analisis bivariat, tidak didapatkan hubungan yang bermakna antara kadar GDP dan latensi P100 pada kedua mata. Hasil ini sesuai dengan penelitian Gupta dkk yang menyelidiki hubungan antara status glikemik dan abnormalitas VEP pada pasien DMT2. ${ }^{19}$ Dalam penelitian tersebut, kadar GDP digunakan sebagai parameter untuk melihat kontrol status glikemik. Hasil penelitian tersebut adalah tidak ditemukan adanya hubungan antara status glikemik dan abnormalitas pada VEP. Korkmaz dkk meneliti aplikasi VEP pada pasien dengan GDP terganggu, namun tidak ditemukan peningkatan latensi P100 dibanding kontrol yang signifikan. ${ }^{22}$

Hasil yang berbeda dilaporkan Rajewski dkk, bahwa pemanjangan latensi P100 memiliki hubungan yang signifikan dengan peningkatan GDP atau HbA1c pada pasien DMT2. ${ }^{23-24}$ Rerata latensi P100 lebih panjang dibandingkan dengan pasien yang memiliki kontrol glikemik yang baik. Perbedaan hasil penelitian ini dapat disebabkan oleh perbedaan parameter status kontrol glikemik yang digunakan. Dalam konsensus, baik GDP dan HbA1c merupakan parameter yang digunakan dalam sasaran pengendalian DMT2 dengan kelebihan dan kekurangannya masing-masing. Pada praktek seharihari, pemeriksaan kadar GDP dapat dilakukan untuk pemantauan hasil pengobatan DMT2, tetapi dapat dipengaruhi oleh faktor variabilitas kadar GDP perhari. ${ }^{1-20}$

Keterbatasan penelitian ini adalah tidak dilakukan pemeriksaan pencitraan otak untuk menyingkirkan lesi asimptomatik, serta tidak 
dilakukan pemeriksaan tambahan menyingkirkan penggunaan obat-obat terlarang. Proporsi jumlah jenis kelamin yang tidak merata dan selisih umur yang besar dapat berpengaruh terhadap interpretasi dan pemanjangan nilai P100. Demikian pula perbedaan level hormonal pada subjek perempuan dapat memengaruhi nilai P100 serta pemeriksaan laboratorium yang hanya berupa penilaian kadar GDP.

\section{KESIMPULAN}

Terdapat pemanjangan latensi P100 pada pasien DMT2 dengan dan tanpa retinopati diabetik serta adanya hubungan yang bermakna dengan korelasi positif kuat antara lamanya DMT2 dan pemanjangan latensi P100.

\section{DAFTAR PUSTAKA}

1. Pengurus Besar Perkumpulan Endokrinologi Indonesia. Konsensus pengelolaan dan pencegahan diabetes mellitus tipe 2 di Indonesia. Jakarta: PB. Perkeni; 2015.

2. Narayan A, Pandurang S, Ahmed M, Kashalikar S. Visual evoked potential changes in diabetes mellitus. Int J Biomed Adv Res. 2015;6(07):537-40.

3. Sasongko MB, Widyaputri F, Agni AN, Wardhana FS, Kotha S, Gupta P, dkk. Prevalence of diabetic retinopathy and blindness in Indonesian adults with type 2 diabetes. Am J Ophthalmol. 2017;2017:1-9.

4. June M, Achuthan A, Ramesh J. Pattern visual evoked potential in non diabetic offspring 's of type II diabetes. JMR. 2015;1(3):83-6.

5. Wisconsin Diabetes Prevention and Control Program Division of Public Health. Diabetes mellitus essential care guidelines. Madison: Department of Health Service State of Wisconsin; 2012.

6. Heravian J, Ehyaei A, Shoeibi N, Azimi A, OstadiMoghaddam H, Yekta A-A, dkk. Pattern visual evoked potentials in patients with type II diabetes mellitus. J Ophthalmic Vis Res. 2012;7(3):225-30.

7. Kumar KVSH, Ahmad FMH, Sood S, Mansingh S. Visual evoked potential to assess retinopathy in gestational diabetes mellitus. Canadian J Diabetes. 2015;2015:1-4.

8. Umashankar, Gunasundari R. A review on electrophysiology based detection of diabetic retinopathy. Procedia Computer Sci. 2015;48:630-7.

9. Hernandez C, Monte MD, Simo R, Casini G. Neuroprotection as a therapeutic target for diabetic retinopathy. J Diabetes Res. 2016;2016:1-8.

10. Zaher A. Visual and brainstem auditory evoked potential in neurology. Dalam: EMG methods for evaluating muscle and nerve function. Egypt: In tech chapter. 2012. h. 281-90.
11. Carter JL. Visual evoked potential. Dalam: Daube JR, Rubin DI, editor. Clinical neurophysiology. Edisi ke-3. New York; Oxford University Press: 2009. h. 311-25.

12. Drislane FW. Visual evoked potentials. Dalam: Blum AS, Rutkove SB, editor. The clinical neurophysiology primer. Edisi ke-1. New Jersey; Humana Press: 2007. h. 461-74.

13. Chopra D, Gupta M, Manchanda KC, Sharma RS, Sidhu RS. A study of visual evoked potentials in patients of type-2 diabetes mellitus. J Clin Diagnostic Res. 2011;5(3):519-22.

14. Gupta S, Gupta G D. Visual evoked potential changes in patients with diabetes mellitus without retinopathy. Int J Res Med Sci. 2015;3(2):3591-8.

15. Odom JV, Bach M, Brigell M, Holder GE, McCulloch DL, Mizota A, dkk. ISCEV standard for clinical visual evoked potentials. Doc Ophthalmol. 2016;133(1):19.

16. Jancic J, Stevanovic D, Popovic MB, Samardzic J. Visual evoked potentials-current concepts and future perspectives. Res Gate. 2016;2016:1-21.

17. Sharma R, Joshi S, Singh KD, Kumar A. Visual evoked potentials: normative values and gender differences. J Clin Diagnostic Res. 2015;9(7):12-5.

18. Emptage NP, Kealey S, Lum FC, Garratt S. Guidelines: diabetic retinopathy. San Francisco: American Academy of Ophthalmology; 2016.

19. Gupta S, Khan T, Gupta G, Agrawal BK, Khan Z. Electrophysiological evaluation in patients with type 2 diabetes mellitus by pattern reversal visual evoked potentials. National J Physiol, Pharmacy Pharmacol. 2017;7(5):527-32.

20. Cheema N, Anwar S, Ehsan E. Visual evoked potential in non-insulin dependent diabetes mellitus patients without diabetic retinopathy. JUMDC. 2017;8(1):1-6.

21. Wang NL. Neurodegeneration in diabetic retinopathy: current concepts and therapeutic implications. Chinese Med Journal. 2016;129(24):3001-3.

22. Korkmaz T, Kisabay A, Hekimsoy Z, Senol E SD. Evaluation of visual pathways using visual evoked potentials in the patiens with impaired fasting glucose and impaired glucose tolerance. Int $\mathrm{J}$ Neurosci. 2018;2:1-0.

23. Rajewski P, Ksiazkiewicz B, Bronisz A, Biesek D, Kamiska A, Ruprecht Z, dkk. Evoked potentials in the diagnostic of central nervous system disorders in diabetic patients. Diabetologia Doswiadczalna I Kliniczna. 2007;7(2):82-96.

24. Lee SS, Han HS, Kim H. Visual evoked potentials in children and adolescent with newly diagnosed diabetes. Turk Pediatri Ars. 2017;52(3):133-7. 